\title{
ENTREVISTA COM PROFESSOR ARNALDO DARAYA CONTIER
}

\author{
La fille de joie est belle \\ Au coin de la rue, là-bas \\ Elle a une clientèle \\ Qui lui remplit son bas \\ Quand son boulot s'achève \\ Elle s'en va à son tour \\ Chercher un peu de rêve \\ Dans un bal du faubourg \\ Son homme est un artiste \\ C'est un drôle de p'tit gars \\ Un accordéoniste \\ Qui sait jouer la java... \\ (L'accordeoniste - Michel Emer, 1942)
}

José Geraldo Vinci de Moraes (JG): Geralmente os primeiros contatos que realizamos com os sons organizados e posteriormente com a música são realizados ainda na infância e na juventude. Como isso ocorreu com você?

Arnaldo Daraya Contier (AC): Devido à sua especificidade, os estudos da música devem se iniciar muito cedo. Aos dezoito anos a formação do aluno deve estar praticamente conclusa. Após essa faixa etária torna-se difícil uma aprendizagem normal mais qualificada. Alguns conseguem prosseguir a carreira, como Magda Tagliaferro (1893-1986); Guiomar Novaes (pianista 1894-1979) e Arthur Rubinstein (1887-1982); a maioria desiste por diversas razões.

JG: E como foi sua formação musical: com professor particular ou em conservatório?

AC: Eu iniciei os meus estudos de música - acordeom e matérias complementares - aos nove anos de idade. Como não havia escolas de música mantidas pelo governo, minha formação musical ocorreu em Conservatório particular 
- Ibirapuera. Mas pelo menos nesta época os conservatórios eram fiscalizados pelo governo estadual, fato que não ocorre atualmente. Estudei acordeom sob influência do ramo israelita de minha família (Goldstein), pois se trata de instrumento cultivado por eles, assim como entre os franceses e italianos. Após a conclusão do curso, dediquei-me ao ensino da educação musical enfatizando matérias teóricas: História da Música, Teoria Musical, Harmonia e Análise Musical. Posteriormente estudei Folclore e obtive o diploma da disciplina no Instituto Histórico e Geográfico de São Paulo, tendo sido aluno de Câmara Cascudo, Rossini Tavares de Lima, Alceu Maynard Araújo, entre outros. Meus professores nessa área eram formados pelo Conservatório Dramático Musical de São Paulo, considerada a escola mais importante de São Paulo. A maioria fora aluno de Mário de Andrade. Depois fiz cursos complementares com o professor Odilon Nogueira de Matos (História da Música no INDAC); Música concreta e eletroacústica com o professor Damiano Cozzella na Pró-Arte, e Estética/ Música Contemporânea com Hans-Joachin Koellreutter. Na Pró-Arte estudei composições e analisei partituras cujos autores eram ainda totalmente desconhecidos no Brasil. Estudei Iannis Xenakis (1922-2001), cujas obras, rigorosas, são freqüências geradas por computador, por meio de detalhados procedimentos matemáticos. Analisei John Cage (1912-1992), o mais original compositor da música ocidental. Seu projeto visava repudiar integralmente a tradição musical. Usou procedimentos aleatórios para libertar a música dos efeitos "coercitivos" das regras e intenções humanas, de forma que os sons pudessem ser "eles mesmos". Travei contato com o vanguardista Luciano Berio (1925-2003), que se destacava pela intelectualidade e técnica. Conheci as obras de Karlheinz Stockhausen (19282007), primeiro compositor a se dedicar à música eletrônica. Suas obras são difíceis de serem executadas em locais convencionais, pois prevêem elementos como foguetes, helicópteros e um apontador de lápis de quatro metros de altura. Outros compositores significativos também fizeram parte desta minha formação: Darius Milhaud, Paul Hindemith, Francis Poulenc, Arnold Schöenberg, Edgard Varèse, Sergei Prokofiev, Dmitri Shostakovich e Benjamin Britten. Como professor, introduzi na sala de aula esses sons "revolucionários” provocando uma verdadeira "revolução estética”.

JG: Bem, os conservatórios tinham estrutura escolar e ofereciam uma formação muito tradicional nos programas de história da música. 
AC: Na realidade o conservatório oferecia uma formação muito tradicional. Nos programas de História da Música o último compositor estudado era o impressionista Claude Debussy (1862-1918). Mário de Andrade, como professor de História da Música e Folclore no Conservatório Dramático e Musical de São Paulo, procurava evitar as obras debussystas, incutindo nos alunos o seu discurso nacionalista e inspirado no folclore brasileiro. Exigia trabalhos inspirados em H. Villa-Lobos, em especial, e trabalhos de pesquisa sobre o folclore. Era preciso ensinar a brasilidade para os alunos pertencentes às elites cafeeiras. Para Mário, o Brasil não havia sido descoberto pelos seus alunos... Paradoxalmente, os meus professores no conservatório, todos discípulos de Mário, nunca citaram, durante os seis anos de curso, nenhuma obra do autor de Macunaíma.

\section{JG: E qual a razão para esse descompasso?}

AC: Creio que o fato de suas obras terem sido editadas pela primeira vez pela Editora Itatiaia, em 1962, contribuiu muito. Além disso, o Folclore não estava incluído na grade curricular das escolas; somente com a Reforma da Lei de Diretrizes e Bases da Educação, o Folclore passou a ser disciplina obrigatória no âmbito do curriculum. Essas condições o afastavam dos currículos dos conservatórios. Meus primeiros contatos com a obra de Mário de Andrade ocorreram somente no curso de folclore no IHGSP. Nesta época mantive contatos com os trabalhos de Renato de Almeida, Rossini Tavares de Lima e Alceu Maynard Araújo. Com o certificado obtido pela Ordem dos Músicos do Brasil (sou sócio desde 1960, n 391 ) passei a ministrar essa disciplina no conservatório. Deste modo, descobri Mário em minhas aulas de Folclore e História, porém, jamais escutei no acordeom nenhum arranjo do autor de Macunaíma, que detestava os instrumentos populares.

\section{JG: Geralmente o repertório de conservatório para o instrumento era o da música erudita.}

AC: O repertório para o instrumento era o da música erudita. Tive como professor um maestro italiano extremamente rigoroso: Giovanni Gagliardi, formado na Escola Santa Cecília, de Roma, muito preocupado com os métodos e repertório. Os métodos baseavam-se numa visão eurocêntrica da cultura, como o Accordion Method de Charles Magnante; Grands Etudes de Concert de Pietro (peças com grandes dificuldades técnicas); Celebrated 
Ouvertures volume one for Accordion; La Técnica Moderna del Fisarmonicista, de Cambieri, Fugazza e Melocchi. O repertório executado também baseava-se em obras de autores estrangeiros, como Johann Strauss, Bach, Dvorak, Chopin, Beethoven, Verdi, Donizetti, Sibelius, Schubert, Wagner, Brahms, Rachmaninoff. No Brasil, nós tínhamos uma tradição de música de concerto de colorações eurocêntricas, privilegiando a Arte Culta e os instrumentos "nobres". Por isso, no acordeom executávamos todo o repertório erudito. Fiz parte da U.B.A. (União Brasileira dos Acordeonistas) e de sua orquestra formada apenas de acordeões. Apresentei-me com ela no Teatro Municipal de São Paulo, Cultura Artística, João Caetano, Paulo Eiró e nos extintos Colombo e Teatro Santana.

Ao mesmo tempo, o acordeom nos anos 50 era muito popular no Brasil graças a Luiz Gonzaga, Carmélia Alves, Fúrio Franceschini e Mário Mascarenhas. Do ponto de vista do conservatório, era visto como um instrumento popularesco, em geral, executado pelas camadas médias e mais pobres da população. Juntamente com o violão, eram vistos como instrumentos de capadócios. A divisão erudito/popular era muito rígida. Eu gostaria de ter aprendido a tocar samba, tango ou mesmo Luiz Gonzaga. Porém toda a minha formação baseava-se em métodos e repertório eruditos. Era impossível, para mim, captar o ritmo de um samba de breque, marchinhas carnavalescas ou outros gêneros.

\section{JG: Na realidade era basicamente o repertório pianístico, transcrito para o acordeom.}

AC: Exatamente: eram basicamente transcrições e muitos arranjos para música de câmara incluíam violino, acordeom e piano. Mas tinha também certa quantidade de peças originais para acordeom escritas pelos estrangeiros. $\mathrm{Na}$ Itália, França e Israel os compositores escreviam para o instrumento. Há, por exemplo, alguns concertos para acordeom e orquestra. Cheguei a tocar duos de peças eruditas de acordeom com violino - meu professor também tocava violino. A gente fazia um duo com peças eruditas. Executava peças eruditas, mas também uma grande quantidade de lieder (canções) escritas pelos grandes compositores da Broadway. Assim surgia outra contradição: executava poucas canções brasileiras, mas possuía um repertório importado dos Estados Unidos (anos 20, 30, 40, momento extraordinário da canção norte-americana). A produção para acordeom nos Estados Unidos, França, 
Itália, Espanha, Israel, entre outros países era numerosa. Os shows de Edith Piaf, Yves Montand, Ute Lemper, Bibi Ferreira, Juliette Greco, entre outros, incluíam o acordeom em seus repertórios, como por exemplo, L’Accordeoniste, grande sucesso desses intérpretes. Os lieder eram muito divulgados, como "My Funny Valentine" - Lorenz Hart/Richard Rodgers (1937); “I love Paris”, Cole Porter (1953); do filme Can-Can, “Allez-vous-en, go away” de Cole Porter (1953), “A Lovely Night” - Oscar Hammerstein e Richard Rodgers (1957), entre centenas de outras canções.

\section{JG: Após se formar no conservatório o senhor já iniciou sua vida profissional?}

AC: Sim. Comecei a lecionar com dezessete anos, no próprio Conservatório Musical Ibirapuera. No Conservatório aplicava técnicas pedagógicas oriundas do colégio e de leituras das obras de Jean Piaget e de Jean Frédéric Frenet. Como professor, refutava tudo que havia aprendido no conservatório e aplicava outras atividades com meus alunos. Alguns dos meus alunos acabaram dirigindo grandes orquestras, no Brasil e nos Estados Unidos. Praticamente quase todos os membros da OSESP foram meus alunos.

\section{JG: E fora das atividades docentes em conservatórios?}

AC: Como professor, fui alargando minhas relações e contatos. Nesta época, por exemplo, conheci o Gilberto Mendes, que me ajudou muito a conhecer música eletroacústica, dodecafônica, aleatória. Acompanhei a criação do Manifesto Música Nova, de 1963. Estas pessoas abriram muito minha cabeça. Conheci também o modernista nacionalista Camargo Guarnieri, fiz várias entrevistas para estudar composição com esse nacionalista convicto e ele dizia: "tudo bem, mas você vai ter que trabalhar com o folclore". Eu respondi que não faria isso, porque o folclore era justamente a base do modernismo nacionalista, algo já ultrapassado nos anos 60 .

\section{JG: A sua formação escolar ocorreu de que maneira?}

AC: Sempre na escola pública; no "Alberto Comte” (Ginásio) e no "Brasílio Machado” (Clássico). Nestas escolas estudei sete anos de latim (quatro no ginásio e três no clássico), filosofia (três anos), com o José Arthur Gianotti, e até canto orfeônico (quatro anos no ginásio). Tive um excelente professor de português - Clemente Segundo Pinho -, muito severo, que nos obrigava a ler Baudelaire, Eça de Queirós e Proust. Líamos um livro a 
cada quinze dias. De literatura brasileira a gente leu os principais autores, inclusive os modernistas, totalmente "esquecidos” no conservatório. Eram escolas excelentes, com ótimos professores, mas todos muito rigorosos. Era uma contradição evidente. Para se conseguir sucesso do aluno, havia uma disciplina "militar": as aulas começavam às seis horas da manhã, inclusive aos sábados. Depois da reforma de 1960 (Lei de Diretrizes e Bases da Educação) houve um enfraquecimento no ensino das humanidades, que se mantém até nossos dias. Algumas disciplinas foram re-incorporadas na grade curricular como Filosofia; outras, como Latim, Grego e Música acabaram sendo eliminadas do curriculum.

\section{JG: E além da formação, digamos, mais institucional, vinculada à escola e ao conservatório, quais as relações que mantinha com o mundo das artes e da cultura?}

AC: São várias as origens. Em primeiro lugar, por questões familiares. Venho de uma família judaica de origem francesa e que sempre deu importância à formação cultural. Meu pai era descendente de judeus alemães e franceses. Em seguida, na época de estudante, me envolvi com o Centro Popular de Cultura. Aqui em São Paulo, o núcleo principal era o Teatro de Arena. Em janeiro de 1969 assisti Eles não usam black-tie, do Guarnieri, e depois A Incubadeira, do José Celso Martinez Correia; Fogo Frio, do Benedito Rui Barbosa. Como o Arena não se fechou num projeto nacionalista endógeno, pude acompanhar também dezenas de peças do repertório internacional e nacional, entre elas Os fuzis da senhora Carrar, Mãe Coragem, Galileu Galilei, de B. Brecht (janeiro de 1969); O Homem de La Mancha, com P. Autran, B. Ferreira e Grande Otelo (musical oriundo da Broadway); Zero à esquerda, com Oscarito, comédia de Mário Lago e José Wanderley (Teatro Esplanada, São Paulo, dezembro de 1963); Antígone, de Sófocles (TV de Vanguarda), com Aracy Balabanian (2 a 6 de fevereiro de 1966); Seis Personagens à procura de um autor (Pirandello), com Paulo Autran, Tônia Carrero (direção de Adolfo Celli, maio de 1960). Ao mesmo tempo freqüentava a série Concerto Sinfônico, no Teatro Municipal, acompanhava a Orquestra Sinfônica Municipal, além de cursos e temporadas de música de vanguarda. Como você vê, as minhas relações com a arte e a cultura eram muito diversificadas e abrangiam contatos constantes com as principais companhias de teatro dramático (Companhia Tônia 
Celli-Autran, Cia. Maria Della Costa); comédia (Oscarito); teatro de revista (Valter Pinto, Carlos Machado); ópera (companhias estrangeiras); cursos de extensão cultural (música de vanguarda), entre outras atividades.

\section{JG: Essa atração pelo teatro veio de onde?}

AC: Inicialmente veio da escola, cujo projeto educativo estava baseado no construtivismo piagetiano. Não tínhamos, por exemplo, aulas expositivas; o aluno construía o seu projeto cultural. E o uso do teatro surgia como alternativa para apresentar a conclusão dos trabalhos. Por causa da música eu freqüentava muito o Teatro Municipal e acompanhava também as peças de teatro. Como tinha amizade com pessoas que moravam no Teatro Municipal, assistia tudo praticamente de graça. Além do teatro, desde jovem fui um cinéfilo. Meu pai tinha uma máquina de cinema mudo e passava em casa para a família as fitas com Rodolfo Valentino, Theda Bara, Charles Chaplin. Depois, acompanhei o cinema falado dos anos 40, 50. Tinha predileção pelos musicais, pelos melodramas, claro. Essa minha atitude era criticada pelos nacionalistas. A esquerda detestava esses tipos de filmes, vistos como alienação. E na época eu era simpatizante do PCB.

JG: Mas você teve vida orgânica no "Partidão”, ou era apenas simpatizante, quando entrou na universidade?

AC: Simpatizante. Ingressei na USP em 1963 e em 1964 fui eleito secretário do grêmio da Faculdade de Filosofia Ciências e Letras. Fui candidato da História, mas sem nenhum apoio político dos meus colegas. O Departamento de História era, em 1964, um grande foco conservador, englobando a maioria dos professores e dos alunos. Houve até agressões de grupos reacionários, em especial logo após o golpe de 1964. Durante a campanha, meus opositores colocaram cartazes tais como: "PerCeBeu, Arnaldo?”. As letras P, C e B em letras visíveis. Apesar desses conflitos - minha vida foi repleta de problemas -, dediquei-me ao Grêmio e gostava muito das atividades políticas, sempre ligadas aos pressupostos cepecistas.

JG: Escutando-o contar todas essas histórias pessoais, percebo que seu artigo sobre Edu Lobo e Carlos Lyra publicado na Revista Brasileira de História tem um tanto de memorialismo, não é? Pois trata justamente de um período em que teve participação direta em sua formação. 
AC: $\mathrm{O}$ artigo fundamentava-se em memórias desse momento histórico. Ambos eram compositores que admirava, sob as perspectivas da melodia e da letra. O Edu Lobo aperfeiçoou sua escrita após sua ida aos Estados Unidos, onde estudou com o Lalo Schifrin. É dele a trilha de Arena Conta Zumbi, de 65, com letra do Gianfranceso Guarnieri. Também acompanhava a produção do Carlinhos Lyra, que à época era diretor do Departamento de Música da UNE. Apesar de sua postura nacionalista e de sua militância no PCB, Carlos Lyra fazia parte de uma geração socialista que assistiu a muitos musicais americanos: Show Boat, Porgy and Bess, Can-Can, My Fair Lady, Cats, Oklahoma, A chorus line, entre outros. Possuía uma formação musical fundamentada na cultura norte-americana. A canção norte-americana continua muito influente entre nossos músicos. Os anos 30 e 40 nos Estados Unidos foram os mais importantes na área da canção. O lied (canção) foi fundamentalmente erudito na Europa na segunda metade do século XIX. Reapareceu nos Estados Unidos com os musicais da Broadway, que nada mais são do que adaptações das operetas. Nas operetas enfatiza-se a melodia. São músicas fáceis de serem cantadas e dançadas. Neste contexto apareceram compositores muito bons: Cole Porter, Rodgers e Hammerstein, George Gershwin. No Brasil eram ignorados pelos cepecistas. Esses lieder eram vistos como canções alienadas e apolíticas. Carlos Lyra diz em seus depoimentos que não tinha nenhum preconceito contra a canção norte-americana. Escutava de tudo e a sua formação era norteamericana. Considero-o como um dos melhores melodistas da música popular brasileira, "Marcha da quarta-feira de cinzas” (1962) possui uma melodia belíssima, muito bem elaborada, acompanhada pela poesia de Vinícius de Moraes. Paradoxalmente com forte teor político.

\section{JC: Apesar disso, o discurso e atuação dele eram marcados pelo engajamento cultural e a dimensão política da canção. $O$ senhor já pen- sava nestas questões nesta época?!}

AC: Na verdade, só mais tarde que eu vim a perceber a relação da música com a política. Eu não via essa relação ainda, porque a arte musical era analisada nos seus aspectos formais. Para mim a música não possuía ligações com a ideologia, a política ou a história. Isso me marcou durante muito tempo. Enquanto que no cinema e no teatro já percebia essas evidentes relações, na música popular ainda não conseguia perceber, apesar das canções proibidas e censuradas durante a ditadura. 


\section{JG: Mas os Centros Populares de Cultura tinham projeto de fazer da mú- sica um instrumento de ação política e apresentavam questões eviden- temente nesta direção.}

AC: Sim, eles fizeram isso. O anteprojeto do Carlos Estevão Martins dividia a cultura musical em três grandes eixos. A música baseada no folclore, que era considerada atrasada, a música da indústria cultural, sem valor estético e a música revolucionária (“Arrastão”, “Caminhando”, “Disparada”).

JG: Mas ao contrário do CPC, o senhor teve uma formação e um escuta musical muito diversificada.

AC: De fato, foi muito diversificada. A minha escuta era plural, tanto no teatro, no cinema, na literatura, como na música; eu não tinha idéias préconcebidas e ortodoxas. Como já disse, no teatro, acompanhei o repertório do TBC, como os grandes clássicos com Cacilda Becker, peças encenadas no Teatro de Arena, Teatro de Alumínio - na Praça das Bandeiras -, companhia de Paulo Goulart e Nicete Bruno, Companhia Maria Della Costa, Companhia Tônia Celli-Autran, entre outras. Na música assistia a Aída no Municipal, mas também freqüentava o Teatro Santana e ia ao Rio de Janeiro ver teatro de revista (Teatro Carlos Gomes e João Caetano). Eu vi todas aquelas vedetes como a Virgínia Lane, Mara Rubia, Darlene Glória, Íris Bruzzi, Marli Marley, Renata Fronzi, e também os cômicos, como Colé e Oscarito. Em São Paulo, as Revistas mais famosas passavam no Teatro Natal e no Esplanada, na Praça Júlio Mesquita.

JG: Digamos que esses não eram espetáculos bem vistos pela intelectualidade e pela universidade, não é?!

AC: Na universidade nem eram citados. Eram considerados espetáculos de “baixo nível”, sem valor estético. Tudo isso era encarado com preconceito pela universidade e pela intelectualidade. Mas o teatro de revista tinha uma parte musical muito rica, além de ser um ótimo entretenimento, uma espécie de contraponto das peças dramáticas.

JG: Paralelo a essa intensa atividade cultural o senhor se formou em História.

AC: Eu era estudante de História, mas não me acostumava muito com os conteúdos de algumas disciplinas. Em 1967, cursava o terceiro ano quando 
fui convidado por um professor de Assis para trabalhar na Faculdade de lá (hoje UNESP). A proposta era relevante e tentadora: tempo integral e ministrar aulas em História do Brasil. Como estava no terceiro ano da graduação, não a aceitei. Assim que me formei, o Professor Eurípedes Simões de Paula convidou-me para assumir a cadeira de Teoria da História, vaga deixada pela Professora Emília Viotti da Costa. Não aceitei o cargo, ocupado então por uma professora portuguesa, pois não conhecia a língua alemã e a minha pesquisa era sobre História do Brasil. Nesse momento aceitei aquele convite para trabalhar em Assis, onde permaneci de 1967 a 1976.

\section{JG: Foi neste momento também que começou a fazer o mestrado com o professor Eduardo França?!}

AC: Sim, meu orientador foi o professor Eduardo d'Oliveira França, na área de Moderna e Contemporânea (1967-69). Entre 69 a 70, graças a uma bolsa, fui para Toulouse desenvolver meu mestrado com o Professor Jacques Godechot. Quando voltei, defendi a tese como doutorado.

JG: Quem financiou sua viagem, já que na época o sistema de bolsa no Brasil era precário?

AC: Minha bolsa foi financiada pelo Ministério das Relações Exteriores do governo francês e a Fapesp pagou minha passagem de ida. A segunda bolsa que obtive, em 1984-85, de pós-doutorado, também foi paga pelo governo francês. Nessas viagens aproveitei também para ampliar os meus conhecimentos.

JG: O que intriga na sua trajetória é essa sua formação multicultural e multimídia, ao mesmo tempo em que tem que trabalhar e conviver no universo cultural formalista e conservador da História.

AC: A sua pergunta é significativa. Quando eu comecei a trabalhar em Assis, posteriormente na UNICAMP e depois na USP, fui obrigado a seguir os textos indicados pelos responsáveis pelas cadeiras, chamados catedráticos, posteriormente professores titulares. Então, o meu mundo na universidade estava dividido em duas partes muito definidas. No início da carreira, por exemplo, eu omitia que era formado em música. Jamais poderia discutir cinema, teatro, literatura ou apresentar uma música em sala de aula. Eu tinha que seguir exatamente a bibliografia que era ministrada aqui dentro, aquilo mesmo que eu havia aprendido. Para a maioria dos professores as artes e questões culturais eram temas a-históricos. 
JG: Mas eu digo do ponto de vista da pesquisa também. Quais eram as possibilidades de diálogo entre arte e história, e desenvolver pesquisas nesta direção?

AC: Bom, minha tese de doutorado não seguiu nessa direção. Ela foi sobre a imprensa em São Paulo (1822-1842), fato que também me causou muitos problemas. Trabalhar com a imprensa nessa época era impossível, pois se tratava de um documento considerado “mentiroso". O professor França censurou o trabalho quando montei o projeto; ele disse que eu não podia fazer uma pesquisa tendo como ponto nodal a imprensa. Para realizar o trabalho, em Toulouse e Paris (Escola de Saint-Cloud), fui estudar lexicologia, semântica, para discutir com rigor os discursos dos jornais visando embasar teoricamente aquilo que era considerado um discurso empírico, "mentiroso”. Foi muito difícil encontrar a documentação. Freqüentei a Biblioteca Nacional. Encontrei o primeiro jornal manuscrito paulistano (1823). Na realidade não é uma tese somente baseada em jornais, pois consultei listas eleitorais, atas do Parlamento, entre outros documentos. Inspirei-me na Semântica, na Lexicologia, na Lingüística para discutir o corpus central da tese. Mesmo assim o professor França foi num primeiro momento intransigente, continuando a afirmar que a minha documentação era "duvidosa”, “falsa”, questionando todas as minhas análises. Então, diante de tantos problemas, eu optei pela erudição, exagerando nas minúcias! Depois de muito trabalho, entreguei a tese em dezembro de 72 e a defendi em maio de 1973. Em 1978, ela acabou se tornando livro, encaminhado à editora Vozes/UNICAMP pelos professores José Roberto do Amaral Lapa e Antonio Cândido.

JG: E de algum modo as angústias do presente vivido sob a ditadura se revelaram ali?!

AC: Claro: para fazer a crítica aos militares no poder eu estudei e critiquei as estruturas de poder na formação do Estado nacional. Não significa que isso tenha relação direta com 64, mas há o interesse em discutir estruturas de poder e revelá-las na sua violência. Mostrei como a mentira e a violência política, moral e pessoal eram partes do cotidiano da elite e como o liberalismo era na práxis pleno de violência. Defendi a tese segundo a qual as palavras estavam dentro do lugar.

JG: De certa forma a atitude interdisciplinar desenvolvida no doutorado foi útil e o preparou para trabalhar mais tarde com a linguagem musical. 
AC: Você colocou bem: eu era professor na área musical e trabalhava com a dissecação da partitura. Gastava um semestre com os alunos para analisar nota por nota de uma "Fuga" de Johann Sebastian Bach (O cravo bem temperado, por exemplo). Era uma forma de erudição que depois aprofundei com o professor Joaquim Barradas de Carvalho. Estudei três anos com ele, após o término do curso. Seu método consistia no estudo do discurso e de cada palavra. Quando tínhamos dúvidas sobre certas palavras, o professor mandava cartas para o Celso Cunha, entre outros intelectuais, e para França, Portugal, Espanha. Na realidade, já trabalhava com a palavra e o som, que me serviu para analisar a música. E a erudição foi o eixo para analisar um discurso verbalizado e uma partitura.

\section{JG: E as atividades com a docência da música corriam paralelas à evolu- ção da vida acadêmica?!}

AC: Sim. E cada vez mais me interessava pelos compositores contemporâneos como Iannis Xenakis, Karlheinz Stockhausen, John Cage. Por isso, fui convidado pelo professor Sigrido Leventhal a apresentar novos conteúdos programáticos para um segundo ano em História da Música, no Conservatório Musical "Brooklin Paulista”, centrando os novos conteúdos programáticos justamente na música contemporânea.

\section{JG: Aliás, o Conservatório do Brooklin foi precursor destes estudos de música contemporânea na cidade.}

AC: Sim, e de certa forma fui eu que comecei os estudos de música contemporânea nessa Escola. Não era fácil. Eu dava aula sobre Xenakis e ninguém gostava - inclusive o Sigrido fechava todas as portas quando ministrava minhas aulas. Alunos e professores não estavam acostumados com os chamados "ruídos". Ingressei no CMBP em 1961 para dar curso de folclore, que era obrigatório, e fiquei até 1980. Com o tempo, entrei em choque com a bibliografia ufanista dos folcloristas. Comecei então a adotar obras de Florestan Fernandes, Isaura Pereira de Queirós, Roger Bastide e mudei completamente o curso! Com essa revisão, acabei refutando o Modernismo nacionalista, todo fundamentado nas palavras "folclore", “povo”, "brasilidade”. E comecei a ler toda a bibliografia modernista, Mário de Andrade, em especial, que posteriormente foram fundamentais na 
elaboração de minha tese de livre-docência, “Brasil Novo, Música, Nação e Modernidade (os anos 20 e 30)”, de 1986.

\section{JG: O senhor acabou publicando um livro, Música e ideologia no Brasil, pela Editora Novas Metas, fundada no CMBP pelo Sigrido Leventhal.}

AC: Anteriormente, em Assis, fui muito incentivado pelo Professor Wilcon Gióia Pereira (Filosofia e Estética) para escrever trabalhos sobre as possíveis conexões entre História, Semiótica, Política e Música. Comecei a discutir as relações entre música, política e ideologia de maneira despretensiosa, em função de um convite da Editora Abril. A história é muito curiosa e começa em 1975 com uma publicação encomendada pelo Itamaraty (via Editora Abril) que queria uma obra trilingüe apresentando a produção artística do país e que seria distribuída nas embaixadas brasileiras. A Abril convocou diversos autores e a seção de história da música ficou sob minha responsabilidade. No Natal deste ano, fui comunicado pela Editora que meu texto tinha sido censurado em Brasília e proibido em todo território nacional, o que me causou certa surpresa, pois a música era uma das artes com menores possibilidades de apresentar questões políticas. Acabei conseguindo uma cópia do texto original, censurado em quase a sua totalidade. Esse texto mais explícito foi publicado na íntegra, sem censura, em 1979, graças à coragem e apoio do professor Sigrido, que possuía uma pequena editora: a Novas Metas. O texto foi publicado sem censura. A primeira edição saiu em 79, em plena ditadura militar, e a $2^{\text {a }}$ edição em 1985.

\section{JG: E a circulação da obra não foi tão restrita assim...}

AC: O tom polêmico e ousado da obra repercutiu no Brasil, França e Estados Unidos. O livro é muito citado na Alemanha. Paradoxalmente, o texto foi refutado antes mesmo de sair publicado. Acontece que um colega nosso do conservatório, o compositor Sérgio Vasconcelos Correia, nacionalista discípulo da escola Camargo Guarnieri, solicitou o rascunho ao Sigrido, a sua primeira versão. Pouco tempo depois passou a escrever uma série de artigos na Folha de São Paulo, atacando o livro ainda no prelo de modo virulento; um deles teve o título "Cala-te, boca", defendendo o Mário de Andrade. Às quartas-feiras, ele escrevia um artigo atacando com virulência trechos do livro. Ele se sentiu ofendido com as críticas que fazia ao Mário e aos nacionalistas. Afirmava que eu estava implodindo o projeto 
modernista, hegemônico dos anos 20 aos 60, no Brasil. Depois ele atenuou suas críticas, pois seus alunos da UNESP ficaram incomodados com suas aulas de composição baseadas em "Carneirinho, carneirão", por exemplo, num momento em que as novas tendências começaram a ser conhecidas pelas novas gerações.

\section{JG: Neste livro finalmente o senhor começa a traçar relações entre a música e a política.}

AC: Isso mesmo! O problema da censura ao meu texto da Abril chamou minha atenção para as conexões entre música, política e ideologia. Comecei a refletir sobre o que já tinha lido sobre o totalitarismo alemão, quando Hitler expulsou Schöenberg, por causa do dodecafonismo, e Kurt Weill, porque executava jazz na rádio alemã. Lembrei-me das peças do Brecht musicadas pelo Kurt Weill, como Mahagonny, e depois as da outra fase, com músicas feitas por Hans Eisler. Na década de 20, Eisler radicalizou suas posições de esquerda e começou a fazer música engajada. Então comecei a importar livros para me aprofundar sobre o assunto e percebi que havia na Europa uma bibliografia sobre ele. Com tudo isso na cabeça, percebi que meus colegas, professores e amigos dos anos 60 tinham um projeto hegemônico na música erudita brasileira, exatamente igual ao de Mário de Andrade. O projeto era profundamente ideológico, escolhendo parceiros, massacrando os adversários e ocupando espaço em Ministérios e Secretarias da Cultura e Educação. De acordo com eles, ninguém poderia sair do modernismo de 1922 e congelaram o projeto no tempo. Ninguém podia fazer nada, a não ser seguir aquele projeto nacionalista. Então resolvi desenvolver um projeto criticando-o e comecei com uma palestra na Sociedade Brasileira para a Ciência, com uma crítica dura ao modernismo brasileiro.

\section{JG: Você poderia citar um trecho censurado pela ditadura e aquele pu- blicado intacto em 1978?}

AC: Texto totalmente suprimido e censurado: "No campo musical, a Semana de Arte Moderna (1922) representou uma tentativa de romper com os temas e técnicas marcadamente europeizantes. Entretanto, esse movimento não refletiu uma ruptura total com a música que tradicionalmente se fazia no Brasil. Mesmo Villa-Lobos, que entre os participantes da Semana foi o que mais inovações apresentou, mostrando simplesmente o resultado de um trabalho que iniciara há vários anos. A maior contribuição da Semana 
foi a de reativar a discussão a respeito das novas tendências da música, levando à definição de uma série de princípios que mais tarde orientaram uma nova face da música brasileira”.

No livro publicado pela Abril o censor apresentou a seguinte "sugestão": “A semana de Arte Moderna de 1922 veio estimular as discussões sobre os caminhos que deveriam ser trilhados pela música brasileira. Essas discussões, que procuravam definir uma posição de distanciamento em relação às tendências europeizantes, presentes em nossa música, resultaram na publicação, em 1928, de um livro de importância fundamental: o Ensaio sobre a Música Brasileira de Mário de Andrade (1893-1945). A proposta central do livro era que os compositores buscassem sua inspiração prioritariamente na realidade nacional, com especial atenção para o riquíssimo folclore musical brasileiro". (Arte Brasileira: p. 95). Neste trecho o censor defende a busca no folclore como ponto nodal do compositor modernista na construção de suas músicas, conforme a tradição da historiografia brasileira sobre essa temática.

JG: Foi neste momento então que começaram a se estabelecer convergências entre História e Música na universidade?

AC: Essas minhas atividades no conservatório, o meu livro e uma série de conferências para a Secretaria de Cultura me deram certa visibilidade, além de meus colegas já terem conhecimento das minhas relações com a música. Como não havia ninguém titulado para participar de bancas com trabalhos sobre música, começaram a me chamar. O Antônio Cândido, por exemplo, me chamou pra examinar as duas teses do José Miguel Wisnik, na FFLCH. A partir desse momento, fui convidado para argüir teses de mestrado, doutorado, livre-docência e titulatura na ECA/USP, UFRJ, UNICAMP, entre outras.

\section{JG: E com relação à pesquisa, o senhor começou a desenvolver a crítica ao nacionalismo modernista e as relações entre música e política que redundam em sua tese de Livre-docência?}

AC: Isso mesmo. Ela tem uma periodização que vai dos anos 20 até o final do Estado Novo. Trato da censura no Estado Novo e discuto questões sobre música popular. Encontrei uma documentação muito significativa e nunca pesquisada. No IEB, por exemplo, encontrei partituras anotadas e comenta- 
das por Mário de Andrade; além disso, sua fabulosa biblioteca estava lá. Inicialmente tive muita dificuldade em manusear esse material, pois havia restrições; tratavam Mário como um mito. Tive que enfrentar os “donos” do IEB para assegurar meus direitos de pesquisador e cidadão para acessar esse material. Na tese, analiso Villa-Lobos por outra ótica, diferente das análises consagradoras. Mostrei suas relações com os chorões e como as elites o detestavam, porque ele lembrava o ritmo sincopado. Mas o sincopado de Villa-Lobos não é o do Anacleto de Medeiros, pois está dentro do viés erudito e ele acaba reinventando a sincopa. Aliás, o conceito de "sincopa" já produziu calhamaços sem fim de papel, sobre sua origem africana. Mas os nossos chorões e compositores eruditos fizeram os atravessamentos melódicos com o que veio da Europa; tudo que é muito matizado, nunca é estudado pelos pesquisadores.

Teoricamente, fui buscar apoio em Adorno. Na música popular, a sua teoria é incompatível, mas para música erudita apresenta questões importantes, quando analisa as condições de produção, debate sobre ideologia e música. Por outro lado, refutei o endeusamento do compositor e sua genialidade produzido pela historiografia romântica, que é a base da história da música tradicional. Uma questão chave na tese é o conceito de "re-significação". A partitura, por exemplo, quando é executada, tem um significado num momento histórico. Quando ela é novamente executada, em outro momento, tem outro significado. Ou então ela pode ser esquecida, e esse fato tem alguma razão; há milhões de partituras que estão nos porões da história, que nunca mais ninguém mexeu. Comecei a fazer um estudo da re-significação do código e percebi que ela é histórica. Deste modo estabeleci a relação da história com a música, a estética e a política.

JG: E a etnomusicologia? Insatisfeita com a musicologia e suas interpretações tradicionais e formalistas, ela surge justamente para entender as relações sociais, políticas e culturais presentes na música popular. $O$ senhor chegou a fazer algum tipo de estudo e diálogo com ela para desenvolver a pesquisa?

AC: Não, mas eu li uma ampla bibliografia sobre essa questão. A etnomusicologia é importante porque se espelha nos diálogos mais diversos possíveis, como com a antropologia. Tive uma aluna, a Mareia Quintero, que fez duas teses muito boas que tratam destes assuntos. Ela fez a relação entre Carpentier 
e Mário de Andrade, estabelecendo conexões entre etnomusicologia e ideologia. Mas eu preferi tratar tudo isso na esfera do dialogismo e da intertextualidade de Bakhtin e outros autores. Quer dizer, como que se dão os diálogos e como ocorrem os atravessamentos entre os discursos e culturas. O dialogismo facilita entender exatamente a novidade da produção artística e como ela foi construída. Por isso prefiro trabalhar com a idéia de culturas, e não de cultura, e analisar seu dinamismo e como dialogam entre si. Eu acredito no singular plural. O que é o singular plural?! É o artista, que escuta mil coisas, capta aqui, ali e acolá, os ritmos, melodias, e estabelece uma síntese (singular). É uma pluralidade de escutas.

JG: Creio que montar a banca de defesa da tese de livre-docência não foi muito fácil ...

AC: Sim, não foi simples. Da área de Contemporânea, que sempre foi minha área, vieram o Carlos Guilherme Mota e o Francisco Calazans Falcon. Ao mesmo tempo, o tema ainda era muito inusitado. No universo das artes e cultura convidei o professor José Teixeira Coelho Netto, da ECA, e a professora de Teoria Literária Walnice Nogueira Galvão, que fez uma belíssima argüição. Por fim, para a música popular convidei Paulo Vanzolini, músico popular e professor ligado à Zoologia.

JG: Sua livre-docência acabou se tornando uma referência na historiografia da música. Nunca houve vontade e oportunidade de publicála integralmente?

AC: Ela é muito grande, quase oitocentas páginas. Eu pretendo fazer uma revisão para torná-la pública. Publico quando tenho vontade ou algo a dizer e não quando a Capes e seus indicadores exigem. Essa política acaba gerando distorções graves. Por exemplo, tem um rapaz do Rio de Janeiro que publicou livro e artigos usando a tese, copiando partes consideráveis dela sem citá-la em nenhum momento.

JG: Além das dificuldades com as fontes e banca, o senhor teve algum outro tipo de restrição, preconceito ou enfrentamento por tratar dessas questões nos cursos do departamento, ou então nas pesquisas?

AC: Até que não tive grandes enfrentamentos porque as pessoas não sabiam bem o que eu fazia. Preconceito existia e persiste até hoje. Os historiado- 
res endógenos, inimigos da interdisciplinaridade, continuam produzindo trabalhos não-criativos.

JC: Diante das oposições, como o senhor fazia para abordar a música nos seus cursos de graduação e pós-graduação?

AC: A minha vantagem foi que tive aceitação in totum dos alunos ao montar os cursos tendo a música como eixo, tanto na graduação, como na pós-graduação. Nesses momentos mais restritivos e de oposições, eu fazia um programa com doze itens, sendo que dois deles eram sobre música. Quando eu ia dar a etiqueta no Antigo Regime, por exemplo, fazia a análise de Don Giovanni, de Wolfgang Amadeus Mozart. Eu estudava toda a estrutura da sociedade, os personagens, ouvíamos as músicas. Os alunos consideravam "uma coisa estranha”. Alguns colegas chegaram a me dizer que não podia trabalhar com ópera, pois isso era assunto para a pós-graduação. Mas eu explicava tudo direitinho aos alunos, depois continuava o curso normalmente. Na pós-graduação, vinha gente da Lingüística, da Engenharia, ECA, Sociologia, Antropologia e Música. Claro que isso criou certa confusão e incômodo lá nos fins dos anos 80. Mas como a aceitação foi grande, algumas professoras até começaram a usar a música como forma de despertar o interesse do aluno pela História. Deram-se mal, claro, porque não conheciam nada e não tinham noção do que estavam fazendo; acabaram desistindo ou confundindo os alunos e a si próprias.

JG: Creio que foi neste momento que o senhor começou a receber alunos que queriam pesquisar...

AC: Ah, veio muita gente e de várias áreas, com projetos, que geraram teses muito boas. Formei muita gente nessa área...

JG: Orientei uma pesquisa que faz um balanço da produção acadêmica realizada nos departamentos de história e que tem como objeto e fonte a música. Há uma dinâmica muito interessante que eu gostaria que o senhor comentasse: justamente no final da década de 1980 começam a aparecer os primeiros e raros trabalhos com essa temática; na segunda metade da década de 1990, há uma explosão de dissertações e teses. $\mathrm{E}$ cruzando as informações, elas revelam que o senhor é o principal protagonista na formação destes pesquisadores e, conseqüentemente, na formação deste novo campo historiográfico. 
AC: É gentileza sua. Mas tudo isso foi acontecendo naturalmente e sem a consciência deste processo. Pelo que expus até agora fica claro que tudo foi uma série de coincidências. De qualquer modo, orientei trabalhos com vários temas de música popular e erudita. Aparecia muita gente e ainda existem alunos que me procuram, sobretudo porque os cursos de pósgraduação em Música têm linhas de pesquisa fechadas. Doutorado só existe no Rio de Janeiro, Bahia e Rio Grande do Sul, e agora na ECA, e examinei boa parte dos professores que estão lá, hoje. Mesmo assim, as linhas de pesquisa destes cursos são muito restritas, como na ECA, que ainda continua muito mal. Como eu trabalho com história da cultura e com música, os horizontes são mais amplos e de acordo com os interesses dos alunos.

\section{JG: E como são os trabalhos acadêmicos dos músicos ou os formados em Música?}

AC: Eles fazem mais uma história muito tradicional, a pior possível. Do tipo “A história do violão"; são super descritivos, mas ao mesmo tempo redigem muito mal; músico não sabe escrever. Mas tem coisas boas também.

\section{JG: Você poderia analisar, em linhas gerais, a produção de teses de seus alunos?}

AC: Oriento dissertações de Mestrado e teses de Doutorado em duas linhas de pesquisa: $1^{\circ}$ ) história política e ideologia, mais relacionada à tese de Doutorado; $2^{\circ}$ ) história cultural e linguagens artísticas. Boa parte deles tem colorações interdisciplinares e transitam por temas e objetos diversos como cinema, teatro e, sobretudo, música erudita e popular. Neste vasto universo, citarei somente alguns destes trabalhos, como Fundamentos históricos e políticos da Música Nova e da música engajada no Brasil a partir de 1962: o salto do tigre de papel, Carlos Alberto de Moura Ribeiro Zeron (Mestrado, USP, 1991); Custódio Mesquita, um compositor romântico. $O$ entretenimento, canção sentimental e a política no tempo de Vargas (19301945), Orlando Barros (Doutorado, USP, 1995); João de Deus de Castro Lobo e as práticas musicais nas associações religiosas de Minas Gerais (1794-1832), Maurício Mário Monteiro (Mestrado, USP, 1995); Fragmentos de Utopias (Oduvaldo Vianna Filho - um dramaturgo lançado no coração de seu tempo), Rosangela Patriota (Doutorado, USP, 1995); $\mathrm{O} \mathrm{Ca}$ nibalismo dos Fracos: História/cinema/ficção - um estudo de Os 
Inconfidentes (1972, Joaquim Pedro de Andrade), Alcides Freire Ramos (Doutorado, USP, 1996); Pan Americanismo, Propaganda e Música Erudita: Estados Unidos e Brasil, Maria de Fátima Granja Tacuchian (Doutorado, USP, 1998); O Estilo Antigo na Prática Musical Religiosa Paulista e Mineira dos séculos XVIII e XIX, Paulo Augusto Castagna (Doutorado, USP, 2000); Adoniran Barbosa - poeta da cidade: a trajetória e obra do radiador e cancionista: os anos 50, Francisco Rocha (Mestrado, USP, 2001); Repertório de Identidades: música e representações do nacional em Mário de Andrade (Brasil) e Alejo Carpentier (Cuba décadas de 19201940), Mareia Quintero (Doutorado, USP, 2002); Carlos Gomes, um compositor orquestral: os prelúdios e sintonias de suas óperas (1861-1891), Marcos Fernandes Pupo Nogueira (Doutorado, USP, 2003); Voz cantada no contexto sócio-cultural, artístico e educacional (problemas e reflexões), Catarina Justus Fischer (Mestrado, Mackenzie, 2004); Magdalena Tagliaferro: Música, educação e Cultura, Andréa Rodrigues (Mestrado, Mackenzie, 2005), Universidade Presbiteriana Mackenzie.

(Depoimento recolhido por José Geraldo Vinci de Moraes em 12/11/2007 e 18/ 02/2008. Transcrição da bolsista de Iniciação Científica Giuliana Souza de Lima) 